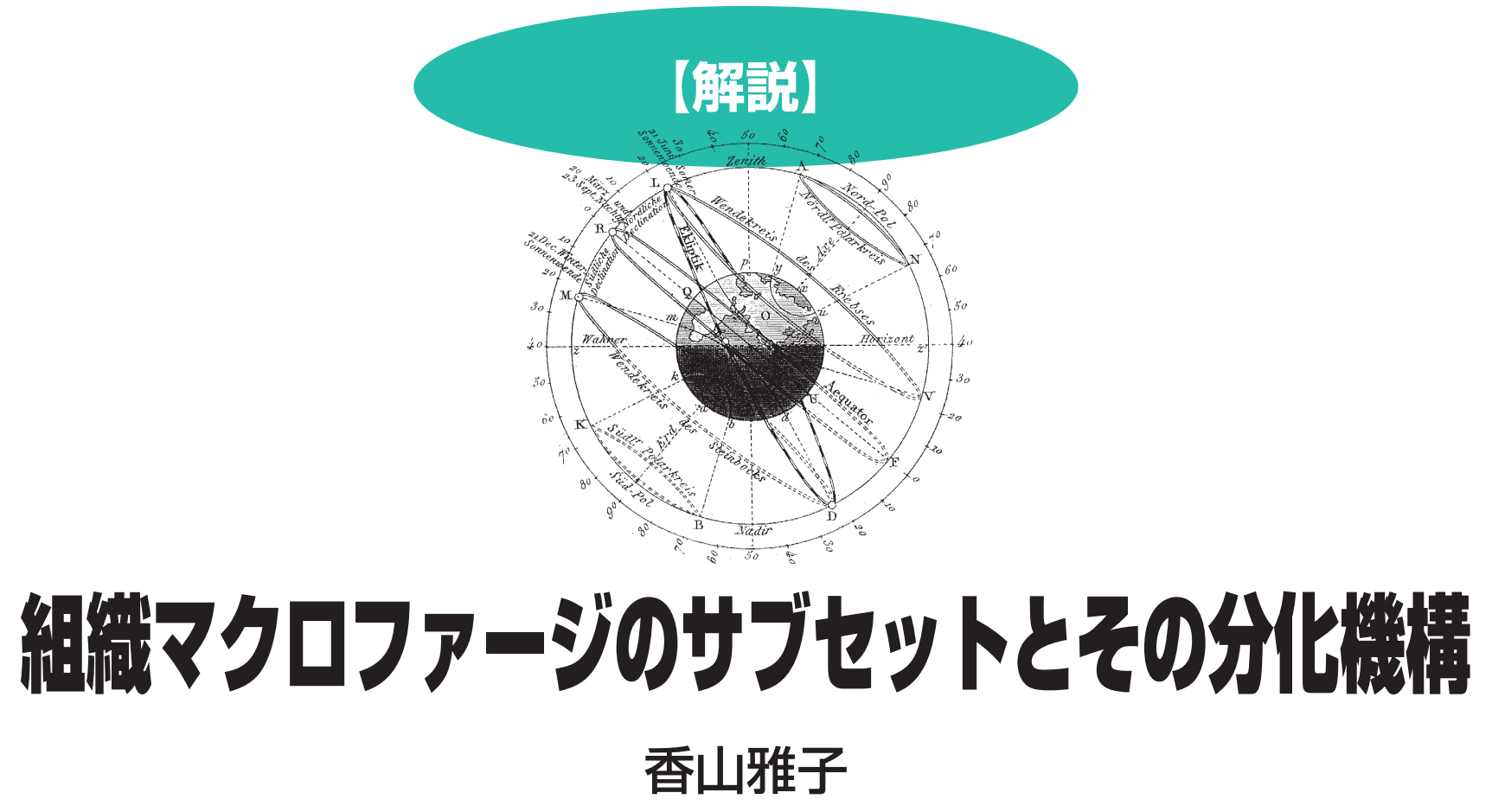

ほぼすべての組織にはマクロファージが恒常的に存在し, こ れらの組織マクロファージは単に免疫細胞として免疫応答に 関与するだけではなく, 組織における恒常性の維持にも関与 すると考えられている．組織マクロファージは存在する組織 によって機能および形態が異なるが，この組織マクロファー ジの多様性を制御する因子（シグナル）については，不明な 点が多い. 本稿では, 組織マクロファージの分化制御機構お よび機能について，脾臓のマクロファージを中心に概説する.

\section{はじめに : 組織マクロファージとは}

19 世紀の生物学者である Ellie Metchnikoffがヒトや下 等動物の組織内で異物を捕捉する細胞を貪食細胞 (phagocyte) と呼び, その形態学的な特徵から貪食細 胞のなかでも単核性の細胞をマクロファージと名づけ た。マクロファージは病原微生物を貪食し, 高度に発達 したリソソームと融合して貪食した病原微生物を分解・ 消化することにより生体防御を担う細胞として知られる ようになった。ささらに, 病原微生物を領食しサイトカイ

The Subset of Tissue Macrophages and Their Development Pathway

Masako KOHYAMA, 大阪大学微生物病研究所免疫化学部門
ンなどの炎症性メディエーターを産生し炎症反応を誘起 するのみならず，分解・消化された病原性微生物由来の ペプチド抗原を $\mathrm{MHC}$ 分子上に提示させ，T細胞を活性 化させることにより免疫応答を誘導する機能ももってい る細胞であることがわかった。

定常状態にてほぼすべての臓器・組織にはマクロ ファージが分布し，これらは組織マクロファージと呼ば れ生体に最も多く存在する抗原提示細胞である（表1）. 現在では，機能的には同じであっても炎症時に誘導され てくるマクロファージとは区別されている．脾蔵内に分 布するRed pulp macrophage（赤脾䯣マクロファー ジ), Marginal zone macrophage (マージナルゾーンマ クロファージ), Tingible body macrophage (可染体マ クロファージ), 肺の Alveolar macrophage（肺胞マク ロファージ), 肝臓のKupffer cell (クッパー細胞), さ らには中枢神経系に分布する Microglia（ミクログリア） 細胞, 骨のOsteoclast（破骨細胞）, 皮膚の表皮中に局 在するLangerhans（ランゲルハンス）細胞など多彩で ある ${ }^{(1,2)}$. これらの組織マクロファージは貪食能を有す るという共通点はもっているがへテロな細胞集団であ り, 存在する藏器さらには局在によって機能・細胞の形 


\begin{tabular}{|c|c|c|c|}
\hline 組織 & マクロファージ & マーカー & 機能 \\
\hline 脂肪組織 & $\begin{array}{l}\text { Adipose tissue-associated } \\
\text { macrophages }\end{array}$ & $\mathrm{F} 4 / 80^{+}, \mathrm{CD} 45^{+}$ & $\begin{array}{l}\text { 脂肪生成, インシュリン感受性の制御, } \\
\text { adaptive thermogenesis }\end{array}$ \\
\hline 血液 & Ly6clo monocytes & $\mathrm{CXCR}^{+}, \mathrm{Ly}_{6 \mathrm{c}^{\text {low }}}, \mathrm{F} 4 / 80^{+}, \mathrm{CSF} 1 \mathrm{R}^{+}$ & $\begin{array}{l}\text { 骨破壊と骨吸収 } \\
\text { 赤血球形成および造血幹細胞の維持 }\end{array}$ \\
\hline 骨 & $\begin{array}{l}\text { Osteoclasts } \\
\text { Bone marrow macrophages }\end{array}$ & 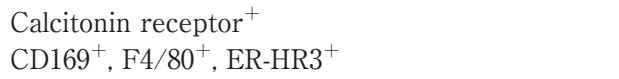 & $\begin{array}{l}\text { 脳分化, シナプス再構成および死神経細 } \\
\text { 胞の除去の促進 }\end{array}$ \\
\hline 脳 & Microglia & $\mathrm{F} 4 / 80^{+} \mathrm{CD} 11 \mathrm{~b}^{+}, \mathrm{CD} 45^{\text {low }}$ & $\begin{array}{l}\text { 腸管のホメオスタシスの維持, 腸内細菌 } \\
\text { の制御 }\end{array}$ \\
\hline 腸管 & Intestinal macrophages & $\mathrm{CXCR}^{\text {high }}, \mathrm{F} 4 / 80^{+}, \mathrm{CD} 11 \mathrm{~b}^{+}, \mathrm{CD} 11 \mathrm{c}^{+}, \mathrm{CD} 64^{+}$ & $\begin{array}{l}\text { 血液中の微生物およびcell debrisの除去, } \\
\text { 感染赤血球や古くなった赤血球の除去 }\end{array}$ \\
\hline 肝臓 & Kupffer cells & $\mathrm{F} 4 / 80^{\text {high }}, \mathrm{CD} 11 \mathrm{~b}^{\text {low }}, \mathrm{CD} 169^{+}, \mathrm{CD} 68^{+}$, Galectine- $^{+}{ }^{+}$ & 吸入に伴い肺胞上皮に沈着した物質の除去 \\
\hline 肺 & Alveolar macrophages & 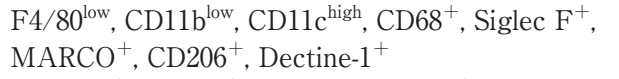 & $\begin{array}{l}\text { 外界より侵入してきた抗原物質をを取り } \\
\text { 込み, T細胞に抗原提示 }\end{array}$ \\
\hline 皮膚 & $\begin{array}{l}\text { Dermal macrophages } \\
\text { Langerhans cells }\end{array}$ & 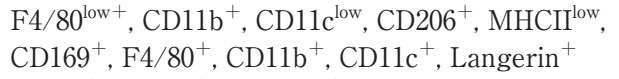 & $\begin{array}{l}\text { 感染赤血球や古くなった赤血球の除去 } \\
\text { 血中由来抗原の取り込み, 免疫寛容の誘導 }\end{array}$ \\
\hline 脾臓 & $\begin{array}{l}\text { Red pulp macrophage } \\
\text { Marginal zone macrophage } \\
\text { Marginal zone metallophilic } \\
\text { macrophage }\end{array}$ & 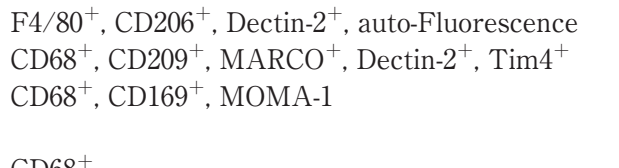 & $\begin{array}{l}\text { 微生物業減退の取り込み, 免疫寛容の誘導 } \\
\text { アポトーシス B細胞の除去 }\end{array}$ \\
\hline & Tingible body macrophage & $\mathrm{CD} 68^{+}$ & \\
\hline
\end{tabular}

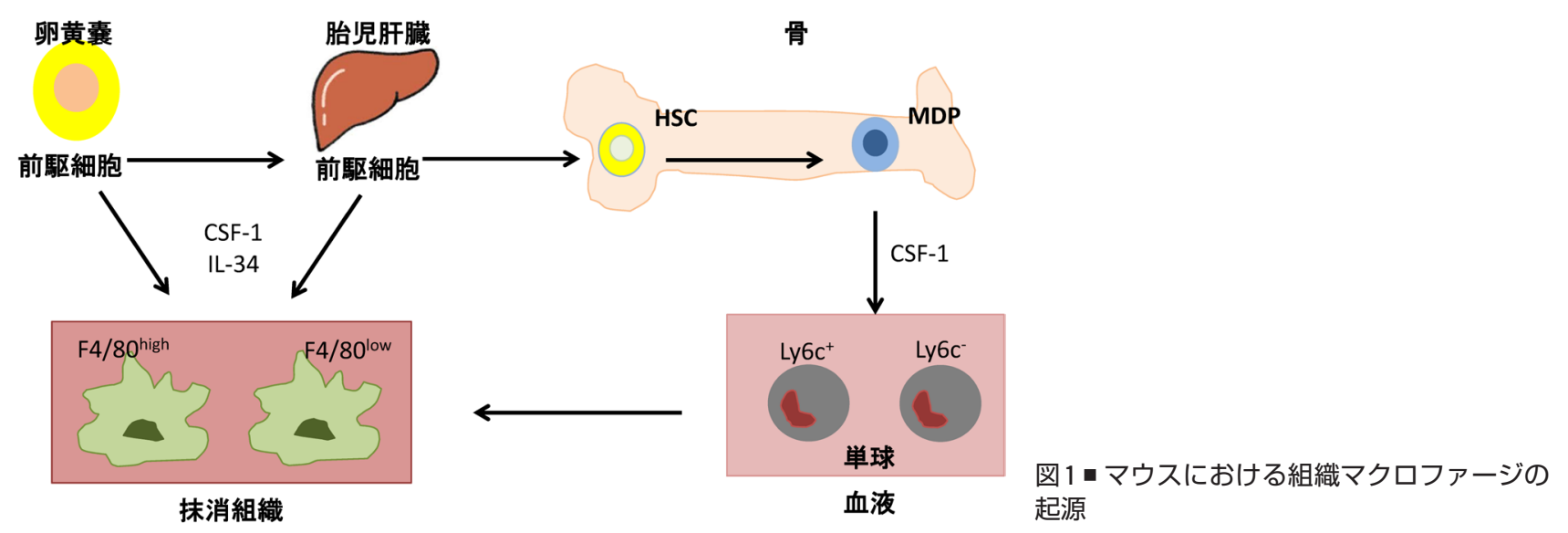

態・細胞表面分子などが異なる。また，これら組織マク ロファージは免疫応答に関与しているだけではなく，古 くなった細胞の除去, 組織の再構築, あるいは炎症応答 後の組織の修復などの役割も担っており, 組織の恒常性 の維持にかかわると考えられている.

\section{組織マクロファージの起源}

1968年にvan Furth とCohnはマクロファージの大部 分は血中の単球より分化するという, Mononuclear phagocyte system (MSP) という概念を提唱した ${ }^{(3)}$.そ の後MSPは組織マクロファージにも当てはめられた ${ }^{(4)}$. つまり骨髄中にある前駆細胞が単球に分化し，さらに組
織マクロファージに分化するという考え方が信じられて きた。 マウスにおいて，マクロファージが作られる “場”は卵黄囊（yolk-sac）の一次造血（primitive hematopoiesis) から AGM (Aorta gonad mesonephros) 領 域，そして胎児の肝蔵へと移行していく．さらに，ほか のリンパ球と同様にマクロファージの発生の場は, 骨髄 で営まれる二次造血系 (definitive hematopoiesis) へと 移行する. 二次造血系が単球（常在性 Ly $6 c^{-}$monocyte および炎症性 Ly $6 \mathrm{c}^{+}$monocyte）の源であり，この単球 より組織マクロファージが分化してくると考えられてき た。

しかし, 単球より MPSが分化してくるという概念は 近年書き換えられつつある（図1）。脳に局在する組織 
マクロファージであるマイクログリア細胞は卵黄囊由来 の細胞を前駆細胞とすること, さらに皮膚に局在するラ ンゲルハンス細胞は卵黄囊と胎児の肝臟に存在する前駆 細胞を起源にもつことがLineage-tracing 実験により明 らかにされた(5)。ささらに，c-myb欠損骨髄を用いた同様 な Lineage-tracing実験により, 脾臓・皮膚・膵臓・肝 臓に存在する組織マクロファージの前駆細胞が卵黄囊に 由来することが示された ${ }^{(6)}$. また，大部分の組織マクロ ファージが卵黄囊あるいは胎児肝臓由来するのに対し て，樹状細胞や F $4 / 80^{\mathrm{low}}$ マクロファージは骨髄由来であ ることも同時に示された (7)。これらの結果より, マウス においてマクロファージの前駆細胞は少なくとも卵黄 囊, 胎児肝臓, そして単球の 3 種類の前駆細胞に由来す ると現在は考えられている.

\section{組織マクロファージの分化誘導機構}

ここまでに述べたように定常状態において組織マクロ ファージの形態抢よび機能が存在する組織さらには局在 によって異なるのみならず，発現する転写因子も異なる ことが報告された ${ }^{(8)}$.この多様性を生む要因として，マ クロファージとマクロファージを支持する周りの細胞と のクロストークによるところが大きい，組織マクロ ファージの多様性を理解するためには, それぞれの分化 を規定する転写因子の同定，およびその作用機序を明ら かにしていく必要がある.

これまで明らかにされている重要な転写因子としては ETSファミリーに属する転写因子である PU.1が挙げら れる.PU.1に変異を加えると CD11b ${ }^{+} \mathrm{F} 4 / 80^{+}$マクロ ファージが完全に消失することにより，その重要性は明 らかである(7). しかしPU.1遺伝子欠損マウスはマクロ ファージのみならずB細胞も欠損するため, PU.1の機 能はマクロファージに限局されたものではない。 また, 同じくETSファミリーに属する転写因子であるETS2 は単球・マクロファージの増殖因子であるサイトカイン であるCSFのレセプターであるCsf1rのプロモーターを 制御することで，マクロファージ分化を制御しているこ とがわかっているが(9)，これもマクロファージに特異的 ではない，さらに成人に抒いては，Mafbが常在マクロ ファージの局所における増殖に必須であることも報告さ れている(6).このように, 組織マクロファージの分化や その維持に必要な転写因子はわかりつつあるが, 組織マ クロファージの多様性を決定している転写因子，つまり は各々の性質や分化を誘導する転写因子については，ほ とんどわかっていない.

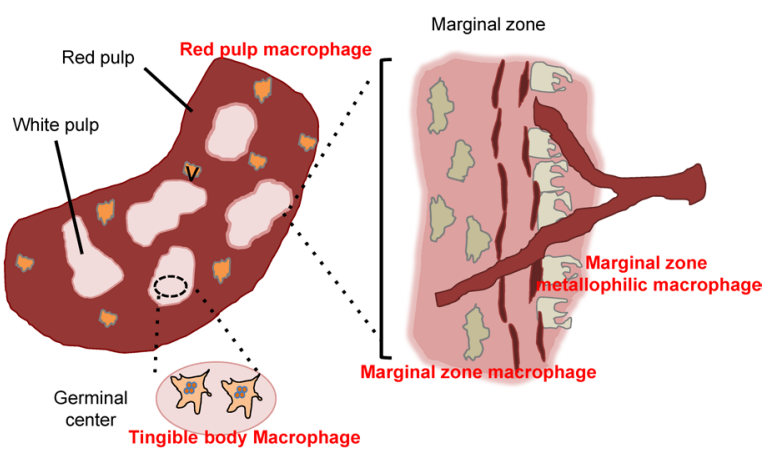

図 2 ロマウス脾臓に存在する組織マクロファージ

文献 10 より改変.

\section{脾臓マクロファージの種類}

脾臓は形態や機能の異なるマクロファージが多数存在 する代表的な臟器の一つである。 マウス脾臟における組 織マクロファージは 1) 赤脾臓に分布するRed pulp macrophage, 2) 白脾臟の周辺に限局してマージナル ゾーン内側に局在する marginal zone metallopilic macrophage と3）その外側に存在する Marginal zone macrophage, ならびに4）白脾臓のリンパ滤胞内に局在する Tingible body macrophagesに区別される(1,2) (図2, 表 1). Red pulp macrophage（RPM）はその局在から古 くなった赤血球や感染赤血球を䓹食し, 脾臟における鉄 のリサイクルに関与していると考えられていたが，直接 生体内で証明されていなかった ${ }^{(2)}$. 従来のマクロファー ジ分化誘導㧍よび機能解析は, 骨髄細胞をサイトカイン （GM-CSF P M-CSFなど）の存在下で培養することによ り行われていた。この方法は成熟マクロファージを容易 にかつ大量に誘導できるというのが利点であるが，機能 的に画一的なマクロファージしか誘導できず，生体内に 存在する「異なる細胞表面マーカーや異なる機能をも つ」組織特異的マクロファージの側面を反映していると は言い難い。また，ある特定の細胞の生体内での役割を 明らかにするためには，その細胞を特異的に欠損してい る動物を利用することが望ましい，そのようなマウスを 作成するためには，その細胞の分化を制御している分子 （転写因子）を同定する必要があると筆者らは考え，ま ず組織マクロファージの分化を規定する転写因子を同定 することを試みた。

\section{Red pulp macrophageの分化誘導機構}

筆者らはさまざまな免疫細胞および正常組織由来の細 胞の遺伝子発現をマイクロアレーにより比較するという 
A

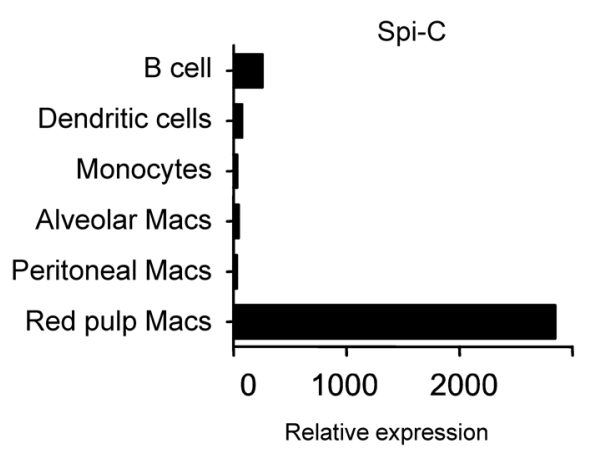

B

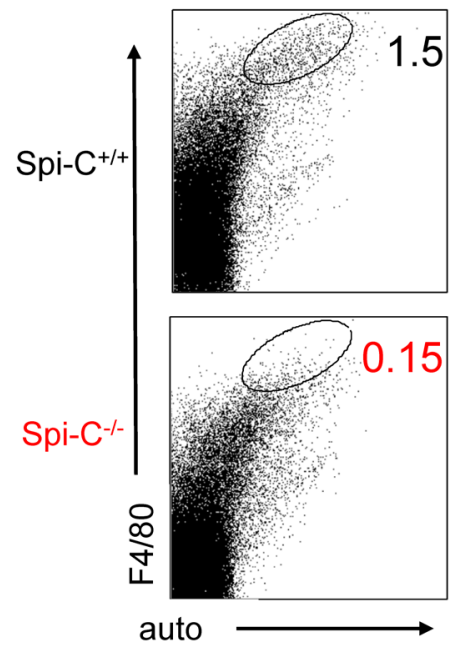

図 3 - 定量PCRによるSpi-C 発現の比較 (A)，およびFACSによるSpi-C 遺伝子 欠損マウスにおける脾臟 F4/80 の発現の 検討 (B)

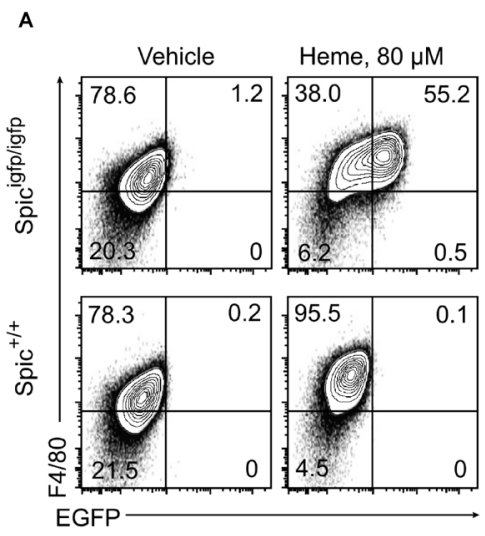

B

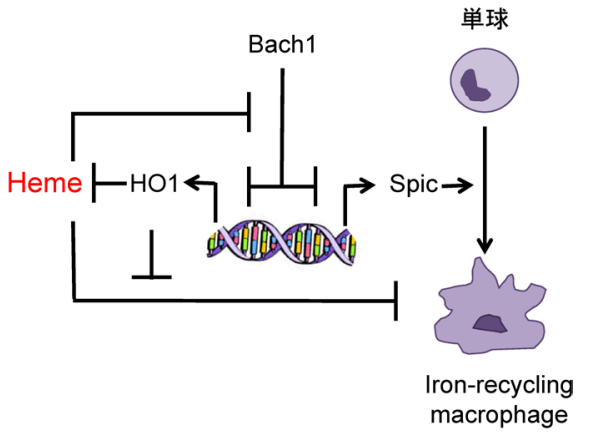

図4 “赤血球の代謝産物であるへムに よってSpi-Cの発現, およびF4/80+細胞 の分化が誘導 $(\mathrm{A})$, 赤血球代謝産物であ るへムによるマクロファージの分化制御 (B)
方法を用いることにより, 脾臓の赤脾䯣に存在する組織 マクロファージ，Red pulp macrophageに特異的に発 現する分子として, ETS familyに属する転写因子 Spi-C の同定に成功した(11) (図3a). 元々 Spi-CはB細胞に発 現するPU.1サブファミリーに属する転写因子としてク ローニングされた転写因子だが，B細胞における機能は いまだにはっきりしていない ${ }^{(12 \sim 14)}$ ，筆者らはRed pulp macrophageにおいてB細胞よりもSpi-Cが高発現して おり,さらにほかの組織マクロファージではほとんど発 現が認められなかったことからSpi-CはRed pulp macrophageの分化を制御している因子ではないかと予想 し，その欠損マウスを作成した. Spi-C 遺伝子欠損マウ スでは脾蔵において Red pulp macrophageを欠損して おり, Marginal zone macrophageといったほかの組織 マクロファージの分化には影響がなかった（図 $3 \mathrm{~b}$ )。ま たRed pulp macrophage と同じくF4/80を発現してい る腹腔マクロファージも野生型マウスと同様に存在して おり, Spi-CがRed pulp macrophageの分化誘導を特異 的に制御していることが明らかになった(11).

\section{赤脾臓に特異的因子による分化誘導}

脾臓Red pulp macrophageの分化が転写因子 Spi-Cで 制御されていることがわかったので，このSpi-Cがどの ようにRed pulp macrophageの分化に関与しているの か, あるいはSpi-Cを誘導するシグナルは何か, Spi-C のターゲット分子は何かといったことを明らかにするこ とが求められる。そこで筆者らはRed pulp macrophage の分化制御を促すシグナル，つまり Spi-Cの発現を制御 しているシグナルは, 組織特異的な因子によって誘導さ れてくるという仮説を立てた. 赤脾臓は古くなった赤血 球を分解し, へムと結合している鉄をリサイクル場と考 えられている。そこでRPMの分化に必須であるSpi-C の発現を制御している組織特異的なシグナル（因子）は 赤脾蔵に特徵的な鉄代謝に関連すると分子と予想した.

そこでin vitroにて赤血球の代謝産物であるへム（老 化赤血球の代謝物質）で刺激するとSpi-Cの発現が誘導 され，さらにはF4/80陽性細胞が分化してきた（図4）. 同時に, SpicがRPM と同様に鉄のリサイクルの機能を 有する $\mathrm{F} 4 / 80^{+} \mathrm{VCAM} 1^{+}$骨髄マクロファージ (BMM) 


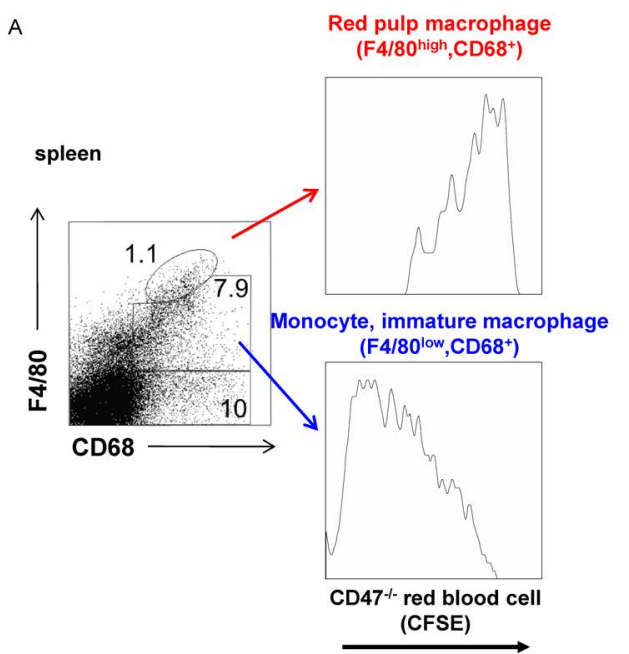

B

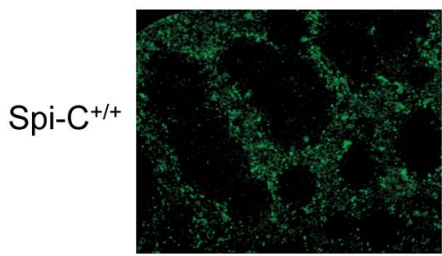

Spi-C-/-

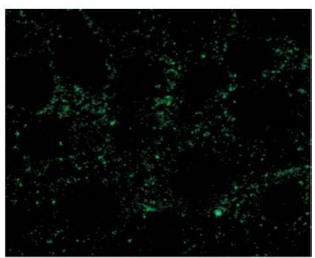

\section{図 5 - 赤血球の取り込み実験}

CFSEでラベルした赤血球を静注し，24時間 後のB6マウスの脾臓を F4/80 と CD68 抗体で 染色し，CFSEの強度を検討 (A). B6マウ スおよびSpi-C 遺伝子欠損マウスの組織切片 によるCFSE発現の比較 (B).

A

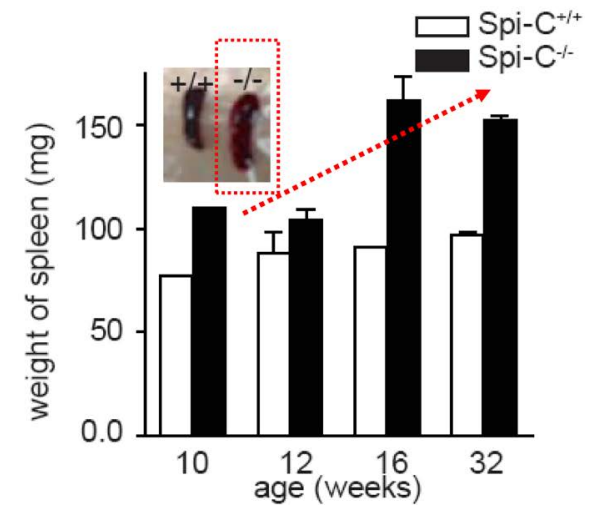

B

Spi-C $+/+$

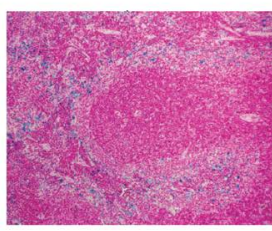

Spi-C-/-

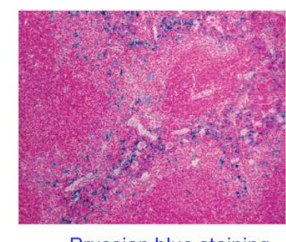

図6-加齢に伴うSpi-C 遺伝子欠損マウス における脾臓の肥大化 (A), および鉄の 異常沈着 (B)
分化も制御することも明らかとなった．過剩なへムは $\mathrm{RPM}$ と BMMのアポトーシスを誘導するが，単球にお けるSpicの発現を誘導しRPM とBMMを分化誘導した. また, Spi-Cの発現誘導はリプレッサーである BACH1 によって阻害された。へムは，プロテアソーム依存的に BACH1 を分解し, Spi-C転写の阻害を解除した。この 結果は，組織マクロファージの分化が代謝物質よって制 御されていることを初めて示した例である ${ }^{(15)}$ (図4).

\section{Red pulp macrophageの機能}

Red pulp macrophageの機能をin vivoで検討する目 的で, RPMによる赤血球の取り込み能を Spi-C 遺伝子欠 損マウスを用いて検討した。オプソナイズした赤血球あ るいはCD47 遺伝子久損マウス由来の赤血球 ${ }^{(16)}$ を CFSE でラベルしてマウスに投与し, 脾蔵中のどの細胞群がこ れらの赤血球を取り込むのかを検討した。すると，脾臓 ではF $4 / 80^{\text {high }}$ と $\mathrm{F} 4 / 80^{\mathrm{low}}$ の細胞群が赤血球を取り达む ことができるが, F4/80highである Red pulp macro- phageによる取り达みが優れていることがわかった (図5).さらにRed pulp macrophageを欠損する Spi-C 遺伝子欠損マウスを用いて同様の実験を行うと，野生型 マウスに比べて赤脾蔵でのCSFEの強度が低くなってお り,このことはRed pulp macrophageが欠損している 脾臓では赤血球の取り込みが悪くなっていることを示し ている (図5)。つまり，脾臓において赤血球はRed pulp macrophageによって除去されることが遺伝子欠損 マウスを用いることにより直接証明された。

また，生まれてくる Spi-C遺伝子久損マウスは正常で あるが，加齢とともに脾蔵が肥大してくる（図6). 面 白いことに，この肥大にはリンパ球の増大は伴っておら ず，代わりに赤血球の異常蓄積が認められた。さらに, 血中の鉄や赤血球の数は野生型マウスと変わらないが, 鉄を染色するペルシアンブルーで脾臓を染めると，野生 型と比較して異常な鉄の沈着が認められた（図6）。つ まり, Red pulp macrophageは脾蔵における鉄代謝に 重要な役割を担っていることが生体内で初めて明らかと なった ${ }^{(11)}$. 
また黒滝らはin vitroの系にて Red pulp macrophage がIL-10やTGF- $\beta$ を産生することで調節性 T細胞 （Treg）を誘導し，自己免疫応答の制御にも関与すると 報告している ${ }^{(17)}$. 実際にRed pulp macrophageがTreg を誘導し, 自己免疫応答を制御しているのかの生体内で の検討が待たれる.

\section{Tingible-body macrophage の機能}

白脾臟の肧中心（germinal center）はB-リンパ球が 成熟分化する場であり，抗原に対して高い親和性をもつ $\mathrm{B}$ 細胞受容体を発現する細胞は生き残り，低親和性受容 体を発現するBリンパ球はアポトーシスに陥り死滅す る(18)。胚中心に存在するCD68陽性の Tingible-body macrophagesは，アポトーシスを起こしたB-リンパ球 を䓹食する．脾臟において Tingible-body macrophages はMFG-E8を特異的に発現している ${ }^{(19)}$. MFG-E8（Milk Fat Globular Protein EGF-8) は，マクロファージが分 泌するタンパク質 ${ }^{(20)}$ で，アポトーシス細胞が提示する リン脂質やホスファチジルセリン (phosphatidylserine) を認識してアポトーシス細胞に結合する因子である(21). Tingible-body macrophagesはMFG-E8を発現してお り, MFG-E8遺伝子を欠損するマウスの脾臟マクロ ファージには領食されないアポトーシスを起こした細胞 が数多く認められ，加齢とともに脾臟が肥大化する.さ らに, 本来存在しない自己抗体 (抗核抗体, anti-nuclear antibody (ANA); 抗DNA抗体) が血清中に増加す るため，マウスは腎炎を引き起こす。これらの結果よ り, 胚中心に存在する Tingible-body macrophagesが, アポトーシス細胞の食食に重要な役割を果たしているこ とが明らかになった ${ }^{(21) .}$

\section{Marginal zone macrophageおよびMarginal zone metallopilic macrophageの機能}

マージナルゾーンはリンパ濾胞を貫通した中心動脈の 枝が赤脾臓と白脾藏の境界部の脾洞内に開口し, 血中の 物質や抗原が脾臓で最初に到達する部位である(2).この マージナルゾーンには 2 種類の組織マクロファージが存 在する。一つは，外側に局在する Marginal zone macrophageは優れた領食能をもち MARCO（Macrophage receptor with collagenous structure), SR-A (Scavenger receptor-A), SIGNR1（SIGN-related1）などの Pattern recognition receptor（PPR）を発現し, 種々の微生病原 体に結合し, 生体防御上重要な役割を担っている ${ }^{(1,10)}$. マージナルゾーンの内側に存在する Marginal zone me-

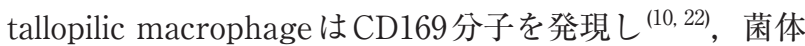
成分の中性多糖類に対する免疫応答に関与する ${ }^{(1,23)}$ ，近 年，マージナルゾーンに局在する 2 種類のマクロファー ジを一時的に消失することのできるマウスを用いて (24) (CD169-DTR mouse), これらのマクロファージを消失 させた後 MOGを発現している細胞を投与すると, MOG に対する免疫寛容が誘導できず，EAEの発症を抑制で きないことがわかった。このことから Marginal zone macrophageが死細胞荟食に伴う免疫寛容の誘導にも重 要な働きをしていることが示された ${ }^{(24) .}$

\section{腹腔マクロファージの機能を制御する GATA6}

岡部らは腹腔マクロファージに着目し, 腹腔マクロ ファージが腹腔特異的なシグナルを感知することで, 腹 腔マクロファージに特異的な遺伝子の発現を誘導する分 子機構を明らかにした ${ }^{(25)}$. 彼らはまず，われわれと同 様にマイクロアレーにて腹腔, 肺, 肝臟, 脾臓, 小腸, 脂肪組織の6つの組織に存在するマクロファージの遺伝 子発現を比較し, 腹腔マクロファージに特異的に発現す るGATA6遺伝子に着目した. GAT A6 欠損マウスにお いて腹腔マクロファージは野生型マウスと同様に存在し たが，腹胩マクロファージに特異的な遺伝子のうち約 40\%の発現が著しく減弱していた。このことは, 腹腔マ クロファージにおいて特異的な遺伝子の発現の多くが転 写因子GATA6に依存して制御されていることを示して いる.そこで, 彼らはGATA6遺伝子の活性化を腹腔マ クロファージに特異的な遺伝子の発現の指標とすること で，組織に特異的なマクロファージの遺伝子発現の分子 機構を解析し，腹腔に存在するレチノイン酸がGAT A6 遺伝子の発現を活性化することを明らかにした，腹腔マ クロファージの分化を制御する因子ではないが，腹脭に 特有のマクロファーの機能の獲得に重要なシグナルが, 組織特異的な因子のレチノイン酸であることを見事に証 明している。

\section{まとめ}

以上，組織マクロファージの分化機構およびそれらの 機能について概説した，その多くは未知のままだが，本 稿で紹介したように少しずつ明らかになってきている. 今後の研究の進展が大いに期待される. 組織マクロ ファージの分化誘導機構の解明が基礎的な研究にとどま らず，マクロファージを標的としたさまざまな疾患の治 療戦略につながっていくことを期待したい. 
1) S. Gordon \& P. R. Taylor: Nat. Rev. Immunol., 12, 953 (2005).

2) R. E. Mebius \& G. Kraal: Nat. Rev. Immunol., 8, 606 (2005).

3) R. van Furth \& Z. Cohn: J. Exp. Med., 128, 415 (1968).

4) R. van Furth et al.: World Health Organ., 46, 845 (1972).

5) F. Ginhoux, M. Greter, M. Leboeuf, S. Nandi, P. See, S. Gokhan, M. F. Mehler, S. J. Conway, L. G. Ng, E. R. Stanley et al.: Science, 330, 841 (2010).

6) G. Hoeffel, Y. Wang, M. Greter, P. See, P. Teo, B. Malleret, M. Leboeuf, D. Low, G. Oller, F. Almeida et al.: J. Exp. Med., 209, 1167 (2012).

7) C. Schulz, E. Gomez Perdiguero, L. Chorro, H. SzaboRogers, N. Cagnard, K. Kierdorf, M. Prinz, B. Wu, S. E. Jacobsen, J. W. Pollard et al.: Science, 336, 86 (2012).

8) D. A. Hume et al.: J. Leukoc. Biol., 92, 433 (2012).

9) G. W. Henkel, S. R. McKercher, H. Yamamoto, K. L. Anderson, R. G. Oshima \& R. A. Maki: Blood, 15, 2917 (1996).

10) P. R. Taylor, L. Martinez-Pomares, M. Stacey, H. H. Lin, G. D. Brown \& S. Gordon: Annu. Rev. Immunol., 23, 901 (2005).

11) M. Kohyama, W. Ise, B. T. Edelson, P. R. Wilker, K. Hildner, C. Mejia, W. A. Frazier, T. L. Murphy \& K. M. Murphy: Nature, 457, 318 (2009).

12) M. Bemark, A. Mårtensson, D. Liberg \& T. Leanderson: J. Biol. Chem., 274, 10259 (1999).

13) S. Hashimoto, H. Nishizumi, R. Hayashi, A. Tsuboi, F. Nagawa, T. Takemori \& H. Sakano: Int. Immunol., 11, 1423 (1999).

14) R. Carlsson, K. Thorell, D. Liberg \& T. Leanderson: Biochem. Biophys. Res. Commun., 344, 1155 (2006).

15) M. Halder et al.: Cell, 13, 1223 (2014).

16) P. A. Olswnborg et al.: Science, 288, 2015 (2000).

17) D. Kurotaki, S. Kon, K. Bae, K. Ito, Y. Matsui, Y. Nakayama, M. Kanayama, C. Kimura, Y. Narita, T. Nishimura

G. D. Victora \& M. C. Nussenzweig: Annu. Rev. Immu nol., 30, 429 (2012).

19) R. Hanayama, M. Tanaka, K. Miyasaka, K. Aozasa, M. Koike, Y. Uchiyama \& S. Nagata: Science, 304, 1147 (2004).

20) J. D. Stubbus et al.: Proc. Natl. Acad. Sci. USA, 87, 8417 (1999).

21) R. Hanayama, M. Tanaka, K. Miwa, A. Shinohara, A. Iwamatsu \& S. Nagata: Nature, 417, 182 (2002).

22) P. R. Crocker et al.: EMBO, 13, 4490 (1994).

23) P. R. Taylor, S. Gordon \& L. Martinez-Pomares: Trends Immunol., 26, 104 (2005).

24) Y. Miyake, K. Asano, H. Kaise, M. Uemura, M. Nakayama \& M. Tanaka: J. Clin. Invest., 8, 2268 (2007).

25) Y. Okabe \& R. Medzhitov: Cell, 157, 832 (2014).

プロフィル

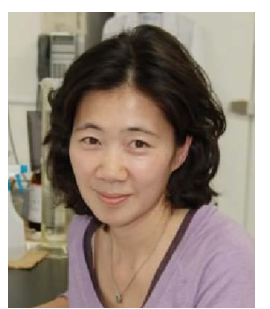

香山 雅子 (Masako KOHYAMA)

<略歴>1992年早稲田大学理工学部卒 業／1994年東京大学農学部農芸化学科修 士課程修了/1997年同大学大学院農学生 命科学研究科博士課程修了/同年理化学研 究所基礎特別研究員 $/ 1999$ 年東京理科大 学生命科学研究所助手 / 2004 年Post Doctoral Fellow, Howard Hughes Medical Institute, Department of Immunology, Washington University in St. Louis / 2011 年大阪大学微生物病研究所助教 $<$ 研究テー マと抱負>マクロファージ，およびその前 駆細胞である単球の分化誘導機構, および その機能の解析<趣味>サッカー観戦, テ 二ス, 家族旅行

Copyright (C) 2015 公益社団法人日本農芸化学会 DOI: 10.1271/kagakutoseibutsu.53.593 